PRZEGLĄD NAUK HISTORYCZNYCH 2020, R. XIX, NR 1

http://dx.doi.org/10.18778/1644-857X.19.01.08

DROBNE PRACE I MATERIAEY

WONA GaLAS

Centrum Studiów Historycznych ${ }^{*}$

(iD) https://orcid.org/0000-0002-6401-4925

\title{
Relacja o słowiańskich Rugianach w średniowiecznych kronikach Helmolda i Saxo Gramatyka
}

Streszczenie. Rugianie, zachodniosłowiańskie plemię zamieszkujące wyspę Rugię, utrzymali znacząca, niezależna od ekspansywnych Niemiec i Danii pozycję aż do XII w. Wówczas Rugia została podbita przez duńskiego króla Waldemara, co nieodłącznie wiązało się z przyjęciem przez pogańskich Rugian chrześcijaństwa. Kroniki Helmolda i Saxo Gramatyka sa powszechnie cytowanymi źródłami w rozważaniach dotyczących słowiańskiego pogaństwa i procesu chrystianizacji plemion słowiańskich. To, co stanowi o dużej wartości obu kronik, mimo subiektywnych ocen dokonywanych przez samych autorów, to zakres ich wiedzy na temat połabskich plemion, w tym Rugian - ich znaczenia wśród innych Słowian, roli kapłanów, wyglądu czczonego wśród nich bóstwa. Przede wszystkim jednak kronikarze szczegółowo opisali podbój Rugii przez Duńczyków, co skutkowało przeorganizowaniem władzy na wyspie i umożliwiło rozwój chrześcijaństwa. Jak dotąd tytułowe kroniki pozostaja głównymi świadectwami tych wydarzeń.

Słowa kluczowe: Słowianie zachodni, Rugia, kroniki średniowieczne, pogaństwo, chrystianizacja.

istoria wyspy Rugii (zwanej także Raną ${ }^{1}$ ), która jest obecnie częścia Niemiec, sięga czasów odległych (VII w.), gdy obszar ten należał do jednego $z$ plemion słowiańskich

* E-mail: pocztaiwony@op.pl

${ }^{1}$ Więcej na temat nazwy wyspy zawiera praca Tadeusza Milewskiego, Pierwotne nazwy wyspy Rugii i słowiańskich jej mieszkańców, „Slavia Occidentalis” 1930, t. IX, s. 292-306. Por. też F. Grucza, Rugia, Rugianie, [w:] Słownik starożytności słowiańskich, t. IV, Wrocław-Warszawa-Kraków 1970, s. 564-565. 
rozrzuconych na terytorium Połabia ${ }^{2}$. Mieszkańcy północnego i środkowego Połabia: Obodryci, Wieleci, Stodoranie, Drzewianie i Ranowie zaliczali się do tej samej grupy językowej - lechic$\mathrm{kiej}^{3}$. Obecność słowiańskich Ranów wyraźnie zaznaczyła się w obszarze basenu Morza Bałtyckiego.

Źródła naszej wiedzy o tym, czym cechowało się plemię Rugian, to kroniki napisane przez średniowiecznych duchownych - Niemca Helmolda $z$ Bosau ${ }^{4}$ i Duńczyka Saxo Gramatyka ${ }^{5}$. Niepiśmienni wówczas Słowianie nie wytworzyli źródeł pisanych, do których można by sięgnać, weryfikując informacje zawarte w obcojęzycznych kronikach. Autorzy opracowania pt. Religia Pomorzan we wczesnym średniowieczu stwierdzili, że: „Brak znajomości pisma spowodował, że Słowianie późno weszli na arenę dziejów" ${ }^{\circ}$. Znane nam przekazy o pogańskich społeczeństwach słowiańskich pochodzą od autorów chrześcijańskich, interpretujących rzeczywistość przez pryzmat Biblii i nauczania Kościoła. Stąd też w nauce funkcjonuje określenie interpretatio Christiana, podkreślające, że była to subiektywna ocena zjawisk i zdarzeń opisanych przez autorów chrześcijańskich ${ }^{7}$. Interpretatio Christiana, cechująca zwłaszcza kronikę Helmolda, dotyczyła przede wszystkim samego stosunku autora do Słowian, który postrzegał ich przez pryzmat prostej, pochodzacej z Biblii, aczkolwiek subiektywnej analogii: naród wybrany - Niemcy oraz pogańskie plemiona, z którymi należy walczyć - Słowianie. Ta analogia niesie ze sobą cały bagaż pejoratywnych wyrażeń i terminów używanych w jego opisach pogańskich Słowian.

2 Ogólny opis Słowian Połabskich przedstawił J. Strzelczyk, Słowianie Połabscy, Poznań 2013. Informacje na ten temat znajdują się także we Wstępie tegoż autora do Helmolda Kronika Słowian, przeł. J. Matuszewski, Warszawa 1974.

${ }^{3}$ R.F. Barkow s ki, Połabie 983, Warszawa 2015, seria: Historyczne Bitwy, s. 18.

${ }^{4}$ Helmoldi Presbyteri Bozoviensis Cronica Slavorum [dalej: Helmoldus], ed. B. Schmeidler, Hannover 1937, Scriptores Rerum Germanicarum in usum scholarum, www.dmgh.de/de/fs1/object/display.html?sortIndex=010:070 (dostęp: $25 \mathrm{~V}$ 2018). (Tłumaczenia fragmentów $z$ języka łacińskiego na potrzeby tej pracy dokonała Autorka).

${ }^{5}$ Ex Saxonis Gestis Danorum [dalej: Saxo], ed. Societas Aperiendis Fontibus Rerum Germanicarum Medii Aevii, Hannover 1892, Monumenta Germaniae Historica, Scriptores [dalej: MGH SS], t. XXIX, s. 43-161.

${ }^{6}$ K. Kajkowski, A. Kuczkows ki, Religia Pomorzan we wczesnym średniowieczu, Pruszcz Gdański 2010, Etnografia dla każdego, nr 2, s. 148.

7 Por. S. Rosik, Interpretacja chrześcijańska religii pogańskich Słowian w świetle kronik niemieckich XI-XII wieku (Thietmar, Adam z Bremy, Helmold), Wrocław 2000, Historia CXLIV, s. 242. 
Istotne jest to, że Dania i Niemcy realizowały konkurencyjną politykę podboju wyspy Rugii. Działania te, rozpoczęte w IX w., podejmowane poczattkowo przez Niemcy pod hasłem „chrystianizacji” pogańskich Słowian, miały na celu zdobycie nowych terenów i nakładanie na nie podatków ${ }^{8}$.

Na Rugii istniał plemienny ośrodek kultu, który z czasem zyskał na znaczeniu wśród innych Słowian i był znany $z$ bogactw zgromadzonych w skarbcu świątyni, znajdującej się w północnej części wyspy, na przylądku Arkona. Fakt ten motywował niemieckich i duńskich władców do prób zajęcia i podporządkowania wyspy. Dodatkowym argumentem inwazji były pirackie wypady, w których Ranowie brali udział, a które stanowiły zagrożenie, m.in. dla duńskich wybrzeży9.

Mimo podejmowanych prób, plemiona słowiańskie rozproszone w rejonie Połabia nie miały wówczas centralnego ośrodka władzy, co stanowiło o słabości Słowian wobec obcych najazdów i ostatecznie doprowadziło do upadku słowiańskiego świata w tym regionie. Alexis P. Vlasto uznał, że: „Fakt, że nie istniała żadna ponadplemienna suwerenność w czasie pierwszego ważnego zderzenia [Słowian - I.G.] z chrześcijaństwem, zdecydowanie znajdzie odzwierciedlenie w ich późniejszej historii” ${ }^{10}$.

${ }^{8}$ Wśród autorów poruszających ten temat istnieje powszechna opinia, że był to główny powód niemieckiej chrystianizacji, co ostatecznie zmusiło Słowian do buntu. Przykładowo Alexis P. Vla s to (The entry of the Slavs into Christendom. An introduction to the Medieval history of the Slavs, Cambridge 1970, s. 148) pisal: „In 983 a great rebellion broke out against the German oppression of taxes and tithe”. Warto również zaprezentować opinię Stanisława Banacha: „While some clergymen like Helmoldus had loftier aspirations for German Christianity, the local Church had a longstanding "hunger for land" and "apetite for rich endowments"”. Por. id em, Saxon, Slavs and conversion: Toward a New understanding of Crusade, "Clio's Scroll” [Berkeley] 2016, vol. XVII, No. 1, s. 33, www.ocf.berkeley.edu/.../Saxon-and-Slavs-and-Conversion (dostęp: 1 II 2018)

${ }^{9}$ Udział Rugian w bałtyckim piractwie Kazimierz Sląski opisuje tak: „W drugiej połowie XI w. aktywność piratów słowiańskich uległa nasileniu, tak, iż na przeciagu blisko stulecia stali się oni postrachem wybrzeży skandynawskich. Szczególnie ujemną opinią cieszyli się mieszkańcy wysp Fehmarn (słow. Wębrza) i Rugii. Szczególnie głośne stały się: napad floty rugijskiej na ówczesną stolicę obodrzycką - Stara Lubekę (1111), najazd Słowian na wyspę Zelandię w r. 1134 [...] Pamięć o owych "królach morza" zachowała się do XIX w. w podaniach ludowych Meklemburgii, Rugii i Pomorza”. K. Śląs ki, Żegluga, [w:] Słownik starożytności..., t. VII, Wrocław-Warszawa-Kraków 1982, s. 236-237.

10 A.P. Vlas to, op. cit., s. 144. 
Bardziej szczegółowe opisy funkcjonowania słowiańskich plemion, dotyczace nie tylko prowadzonej przez nie polityki, zostały scharakteryzowane w tytułowych kronikach. To właśnie one pozostają jak dotąd istotnym źródłem informacji o Rugii, mimo kulturowej obcości autorów.

Kronikarz Helmold urodził się prawdopodobnie między rokiem 1118 r. a 1125 r. Był proboszczem w Bosau, jednak zanim obją probostwo, przebywał w Segeburgu i Oldenburgu. Praca nad kronika podzielona była na dwa etapy; dzieło powstało najprawdopodobniej między rokiem 1167 a 1172 . Piszac swoją kronikę, Helmold czerpał $z$ tradycji ustnej, również $z$ wcześniejszych przekazów, a także $z$ relacji świadków. Celem jego pracy było opisanie procesu chrystianizacji pogańskich Słowian żyjacych na wschód od Sasów ${ }^{11}$ - tak w wielkim skrócie można przybliżyć postać i pracę Helmolda nad jego kroniką. Dzieło Saxo Gramatyka Gesta Danorum $z$ kolei odnosi się do historii duńskiej, a momentami także nordyckiej. Prace nad kronika autor rozpoczą być może w 1185 r. (na tym roku kończy się kronika), natomiast ostatnia, 16 księga została zakończona prawdopodobnie po roku 1200. Ostatnie trzy księgi Gesta Danorum opisuja podbój Rugii i Pomorza Zachodniego przez Danię ${ }^{12}$. Autorzy obu kronik czerpali z dzieł już istniejących, opisujących dzieje pogranicza sasko-słowiańskiego, m.in. z kroniki Adama $z$ Bremy.

Informacje na temat Ranów w obu źródłach doczekały się wielu opracowań. Badacze tematu poddali je historycznej, religijnej i kulturowej krytyce, niemniej jednak obie kroniki są nadal uważane za źródło najbardziej obszernych opisów funkcjonowania społeczeństwa słowiańskiego na wyspie Rugii.

To, co przekazuje nam Helmold w swojej kronice o słowiańskich Ranach, to przede wszystkim ich prymat w słowiańskim świecie: „najmężniejsi spośród Słowian”13, „żadna decyzja w sprawach plemiennych nie może być podjęta bez konsultacji z nimi”"14, „przewodniczą całej Słowiańszczyźnie"15. Ponadto Helmold pisze o nich,

${ }^{11}$ S. Banach, op. cit., s. 29-30. Zbliżona opinia na temat celu pracy Helmolda: S. Rosik, op. cit., s. 231.

12 O życiu i twórczości Saxona Gramatyka por. Od Tłumacza, [w:] Saxo Grammaticus, Gesta Danorum kronika Danii, przeł. J. Wołucki, Sandomierz 2014, Biblioteka Tradycji Europejskiej, nr 52, s. 452-454; oraz Saxo, s. 37-43.

${ }^{13}$ Helmoldus I, 2, s. 9.

${ }^{14}$ Ibidem.

15 Ibidem, s. 70. 
że jest to plemię ludzi, którzy: „mają własnego króla”16. Stwierdzenie to jest kwestią trudna do rozstrzygnięcia; o niej jeden $z$ badaczy tematu pisze: „Nie pojmując słowiańskich systemów politycznych i religijnych, obserwatorzy używali w swych opisach znanej im terminologii. Odzwierciedla się to na przykład w różnych formach tytularnych nadawanych władcom plemiennym, których zwie się na przemian rex (król), dux (książę), princeps (książę zwierzchni), regulus (pomniejszy król) [...] trzeba mieć jedynie na uwadze, że synonimy owe nie sa adekwatne do nowożytnej nomenklatury"17. Wydaje się jednak, że niezależnie od interpretacji nazw w słowiańskim świecie, przez ten sposób określenia władcy kronikarz stara się nadać Ranom najwyższą rangę wśród plemion słowiańskich.

Interesująca, ale nierozwiązaną kwestia pozostaje w społeczeństwie Ranów również rola kapłana świątyni, o którym Helmold odważnie pisze: „Król nie ma takiego autorytetu u nich, jaki ma kapłan [...]. Kapłan zależy od wyroku losu, a król i lud od woli kapłana"18. Dodatkowo kapłan, zgodnie $z$ tą relacją, pełni różne inne funkcje społeczne, np. rolę posła podczas prób prowadzenia układów z księciem Henrykiem [Gotszalkowicem] ${ }^{19}$. Oczywiście sprawuje kult ${ }^{20}$, ale również decyduje w sprawach wojennych ${ }^{21}$.

W opisie samego plemienia Ranów kronikarz używa pejoratywnych słów, zwłaszcza w odniesieniu do ich nieskłonnej do nawrócenia postawy: „okrutny naród”22, „[plemię] ponad [wszelka] miarę oddane bałwochwalstwu” "23, „plemię Rugian [było] bardziej oporne [w przyjęciu wiary] niż inne [plemiona]" ${ }^{24}$, „[Rugianie] w ciemnościach niewiary [pozostaja] do naszych czasów"25.

16 Ibidem, s. 9.

17 R.F. Barkowski, op. cit., s. 25. Szerzej kwestie tytułów rex i dux w X w. omawia K. Modzelew ski, Barbarzyńska Europa, Warszawa 2004, s. 403-405.

${ }^{18}$ Helmoldus II, 108, s. 213.

${ }_{19}$ Helmoldus I, 38, s. 76.

20 Ibidem, s. 73-77.

${ }^{21}$ Warta uwagi jest opinia A.P. Vlasty (op. cit., s. 145), który sugeruje, że zasięg władzy kapłanów był wśród Słowian jeszcze większy: „Moreover the priestly office had apparently reached full development among them - a situation which we cannot clearly see in any other Slav area. This meant that the priesthood could organize resistance even if the tribal chieftain was prepared to submit".

${ }^{22} \mathrm{Helmoldus} \mathrm{I,} \mathrm{36,} \mathrm{s.} 70$.

${ }^{23}$ Ibidem.

${ }^{24}$ Ibidem, s. 212.

25 Ibidem. 
Pośród innych plemion słowiańskich Rugianie najdłużej opierali się chrześcijaństwu. Oprócz być może cech samego plemienia Ranów sprzyjało temu położenie geograficzne - morze zamarzało na zimę, gdy warunki do walki były niekorzystne, i topniało wiosna, co sprawiało, że wyspa Rugia stawała się trudniejsza do zdobycia ${ }^{26}$.

Ekspansja chrześcijaństwa na wyspę, według Helmolda, nastąpiła już w czasach Ludwika II w IX stuleciu. Autor kroniki powołuje się na tzw. legendę korbejską, która zawiera wyjaśnienie pochodzenia rugijskiego bożka Świętowita, i opisuje wyprawę misyjna do Rugii mnichów $z$ Korbei we wcześniejszych wiekach ${ }^{27}$. Niemcy, a później również Duńczycy, wielokrotnie podejmowali próby podboju oraz chrystianizacji wyspy. Ranowie przyjmowali chrześcijaństwo i po krótkim czasie powracali do słowiańskich wierzeń. Konwersja występowała na zmianę $z$ apostazją do wieku XII ${ }^{28}$.

Tak jak Ranom Helmold przyznaje pierwszeństwo wśród Słowian, tak ich bóg Świętowit zajmuje pierwsze miejsce wśród słowiańskich bogów: „[udzielał] trafnych wyroczni, [byl] bardzo chwalony za zwycięstwa, [które zapowiedział]"29. Widoczne jest to zwłaszcza w określeniu: „[uważany był] za boga bogów”30. Kult Świętowita raczej nie obejmował całej Słowiańszczyzny; bożek i świątynia, w której stał, odgrywały większe znaczenie dopiero po roku 1067, gdy upadła Radogoszcz, pełniąca funkcję centrum religijnego do tego momentu ${ }^{31}$.

${ }^{26}$ Przykładowo Helmold relacjonuje druga wyprawę księcia Henryka na Rugię, zakończoną klęską ze względu na to, że „intravit terram Rugianorum cum magno Slavorum et Saxonum exercitu. Vixque tribus noctibus ille remanserant, et cepit hiems resolve et glacies liquescere, contigitque, ut imperfectis rebus revertentes marina pericula vix evaserint". Helmoldu s I, 38, s. 73-77.

${ }^{27}$ Hipotezy związane $z$ ustaleniem prawdziwości korbejskiej legendy wyczerpująco przedstawił J. Sos zyński, Święty Wit a Świętowit Rugijski. $Z$ dziejów legendy, „Przegląd Humanistyczny” 1984, t. XXVIII, nr 9/10, s. 133-139.

${ }_{28}$ Więcej szczegółów dotyczacych kwestii konwersji i apostazji Rugian znaleźć można w artykule autorki tej pracy: I. Galas, Od religio do superstitio wśród Słowian Połabskich według kronikarza Helmolda, [w:] Odkrywanie Europy Środkowej - od mitologii do rzeczywistości, red. M. Danielewski, R.R. Tomczak, Poznań 2016, Publikacje Instytutu Historii 143, s. 25-32.

${ }^{29}$ Helmoldus II, 108, (12), s. 213.

${ }^{30}$ Ibidem. Opinie co do znaczaccej pozycji bożka Świętowita wyraża większość autorów opracowań dotyczacych tego zagadnienia - przykładowo A. Gi eys ztor, Mitologia Słowian, Warszawa 2006, seria: Communicare, s. 117-130; H. Łowmiański, Religia Słowian i jej upadek, Warszawa 1986, s. 166-202. Wspomniany A.P. Vla s to, op. cit., s. 149 konkluduje: „Helmoldus' description of Svantovit at Arkona as deus deorum is only relatively true; the Dane Saxo is more accurate in stressing Svantovit's strictly tribal authority - an internal but not an external intolerance".

${ }^{31}$ Również tutaj istotna wydaje się opinia A.P. Vlas ty (op. cit., s. 149), który słusznie akcentował rolę kultowych stolic słowiańskich (Radogoszcz, a co za tym 
Co do wyglądu bożka i samej świątyni, a także sprawowania kultu, należy oddać głos narracji Saxo Gramatyka. W ostatnich rozdziałach jego kroniki znajduje się opis ostatniej duńskiej inwazji na Rugię w celu zdobycia wyspy. Atak ten formalnie zakończył walkę ze słowiańskim pogaństwem ${ }^{32}$. W tym miejscu kronikarz zawarł bardzo szczegółowy opis samego posagu bożka: „Posag [był] godny podziwu, wielkością przewyższał ludzki wzrost; stał [opatrzony] czterema głowami i taką samą liczba szyi. Można było zauważyć, że dwie [głowy] zwrócone były przodem, pozostałe tyłem. $Z$ tych [głów] zwracajacych się tak do przodu, jak i do tyłu, jedna wydawała się zwracać w lewo, druga w prawo [...].

$\mathrm{W}$ prawej ręce [posąg] trzymał róg, wykonany z różnych rodzajów metalu [...] Nieopodal [posagu] widoczne były: uprząż i siodło oraz liczne zaszczytne oznaki bogactw. Podziw nad nimi rósł [ze względu na] miecz o widocznej wielkości, którego pokrywa i rękojeść zwracały uwagę wyjątkowym pięknem dzieła, wykonanego w srebrze [...].

Ten posag, czczony daninami [składanymi] przez całą Słowiańszczyznę, obdarowywany był również przez sąsiednich królów, którzy nie uznawali tego za świętokradztwo"33.

Temu właśnie kronikarzowi zawdzięczamy opis sprawowania obrzędów i kultu przez kapłana, związanych z bożkiem Świętowitem i poświęconym mu ośrodkiem religijnym, znajdującym się na przylądku Arkona ${ }^{34}$.

idzie - również Arkonę) jako rdzeń słowiańskiej tożsamości, pisząc: „The Germans by now understood that to destroy the sanctuary was to destroy the tribe. Resistance would then collapse since its god had been conquered by a stronger god and could never be rehabilited". Wydaje się, że ten sam wniosek kierował zamiarami króla Waldemara podczas zdobywania Rugii w 1168 r., który był równieź świadomy, że: „exstante simulacro, facilius gentis menia quam sacrilegia domarentur”. Saxo XIV, s. 123. O oczywistym celu demonstracyjnego niszczenia posagów słowiańskich Karol Modzelewski (op. cit., s. 458) napisał: „Była to zamierzona demonstracja, rozmyślne świętokradztwo, które miało wykazać poganom bezsiłę ich bóstwa i tą droga przekonać ich do porzucenia tradycyjnego kultu".

${ }^{32}$ Szerzej o oblężeniu Arkony, a także o znakach-symbolach odzwierciedlajacych największe wartości plemienia Rugian pisze J. Banaszkiewicz, Czym była i jak została zniszczona choragiew Świętowita (Saxo Grammaticus, Gesta Danorum, XIV, 39, 14 - 28), [w:] W stronę rytuałów i Galla Anonima, Kraków 2018, s. $133-153$.

${ }^{33}$ Saxo XIV, 20-35, s. 122.

${ }^{34}$ Ibidem, s. 122-123. Przy tak szczegółowym opisie nie bez podstaw pozostaje opinia A.P. Vla s ty, op. cit., s. 146, który stwierdza: „Saxo may have been an eyewitness of the destruction of Arkona in 1168". 
Spośród informacji zawartych na temat mieszkańców Rugii w kronice duńskiego autora istotny jest przede wszystkim szczegółowy opis najazdu duńskiego króla Waldemara w roku 1168. To właśnie Dania, sprzymierzona z Sasami i Pomorzanami, ostatecznie zwyciężyła w walce o panowanie na niej oraz zawłaszczenie świątynnego skarbca na wyspie ${ }^{35}$. Waldemar, z pomoca biskupa Absalona, podbił Rugię, w tym Arkonę - religijne centrum Słowian, co niosło ze soba koniec słowiańskiego świata w jego niezależnej, przedchrześcijańskiej formie. Opis zniszczenia świątyni, a przede wszystkim bożka Świętowita jest spójny w obu kronikach: król Waldemar na oczach mieszkańców miasta nakazał przeciagnąć posag, związany linami, ze świątyni do obozu, a następnie został on porabany na kawałki. Świątynia została zburzona i złupiona ${ }^{36}$.

Podbój Rugii był faktem bardzo istotnym w ówczesnym świecie. Warto wspomnieć, że zapisy na ten temat znajdują się w większości tekstów źródłowych $z$ tamtych czasów:

1) 1170. Ruia a Danis acquisita est et ad fidem Christi Conversa. 17. Kalendas Iulii baptizatus est Iarmarus cum ceteris Sclavis ${ }^{37}$.

2) 1167. [...] Hic Sclavi Røbo acceperunt Cristianitatem, iubente Waldemaro rege, $17 \mathrm{Kal}_{\text {. Iulia }}^{38}$.

3) [...] Eodem etiam Anno Rö in Sclavia a Danis est victa et ad fidem Christi conversa ${ }^{39}$.

4) 1170. [...] Ro a Danis devicta est ${ }^{40}$.

5) Tum Waldemarus rex iterum edixit expeditionem et in Rugianos profectus est et advenit die pentecostes et cepit oppidum Arconam, quod antea commemoratum est. [...] Tum rex eos iussit

${ }^{35}$ Dokładną analizę stosunków między Pomorzanami, Duńczykami a Sasami w sojuszu przeciwko Rugii oraz jego wyniku, na mocy którego Rugia przypadła Duńczykom, opisał K. Myślińs ki, Bogusław I książę Pomorza Zachodniego, Bydgoszcz-Gdańsk-Szczecin 1948, s. 23-24.

${ }^{36}$ Helmoldus II, 108, s. 212; Saxo XIV, s. 127.

37 Ex Annalibus Waldemarianis et Vitecolensibus, MGH SS, t. XXIX, s. 178. Dyskusyjna kwestia daty, która różni się o dwa lata w stosunku do faktycznego roku wydarzeń, powtarzana również w innych źródłach, zostaje rozstrzygnięta jeszcze w tym samym miejscu kroniki przypisem: $1170-$ „Falsum hunc annum etiam alii praebent".

38 Annales Lundenses, MGH SS, t. XXIX, s. 205.

39 Ex Chronica Danorum Sialandica, MGH SS, t. XXIX, s. 213.

40 Annales Essenbecenses, MGH SS, t. XXIX, s. 224. 
christianam fidem recipere [...] et iussit eum destruere idolum, quod Svantavit vocabatur, et ex oppido extrahere, templum spoliare $[\ldots]^{41}$.

6) 1170. Baptizati Iarismarus et Slavit2.

Wkrótce poddał się również gród Charenza, będący polityczna stolicą Ranów. Przywódcy złożyli Duńczykom hołd lenny, co zainicjowało istnienie Księstwa Rugijskiego z własną dynastią rozpoczynająca się od księcia Jaromara I. Księstwo obejmowało także część terytoriów na kontynencie położonych naprzeciwko wyspy ${ }^{43}$.

W celu chrystianizacji wyspy Jaromar I nakazał budowę kościołów, a Duńczycy osiedlili na wyspie cystersów. W tym okresie przybyło tam wielu niemieckojęzycznych kolonistów, wypierając ludy słowiańskie.

Lektura kronik Helmolda i Saxo Grammatyka unaocznia przede wszystkim to, że rdzennymi mieszkańcami terytoriów na zachód od Odry byli Słowianie, którzy przez długi czas toczyli walkę z nieuniknioną wówczas, nadchodząca nieuchronnie zmianą znanego im słowiańskiego świata.

$\mathrm{Na}$ terytorium dzisiejszej Rugii, na arkońskim przylądku, prowadzone sa badania archeologiczne. Trudno nie zaznaczyć, że jest to już ostatni czas na nie ze względu na fakt, że Morze Bałtyckie sukcesywnie zmniejsza obszar kredowego klifu. Terytorium, gdzie stała świątynia arkońska, zostało już dawno zabrane. $Z$ doniesień prasowych na temat aktualnych badań wiadomo, że archeolodzy znaleźli pozostałości po nieznanej dotychczas budowli, która mogła służyć Słowianom do celów kultowych. Niemieccy naukowcy twierdzą, że fundamenty budowli, szczególnie ich zarys przypominający kształt statku, wskazuja na skandynawskie wpływy ${ }^{44}$.

Wykopaliska przywracaja świadomość o pierwotnych mieszkańcach wyspy i $z$ pewnościa stopniowo będą rozszerzać wiedzę na temat życia i kultury słowiańskich Ranów, uzupełniając historię zapisaną w średniowiecznych kronikach.

${ }^{41}$ Ex Historia Regum Danorum Dicta Knytlingasaga, MGH SS, t. XXIX, s. 313.

42 Ex Annalibus Islandicis, MGH SS, t. XXIX, s. 259.

43 J. Strzelczyk, op. cit., s. 105.

${ }^{44}$ Zwięzłe doniesienia prasowe na temat znalezisk archeologicznych na Rugii zaprezentowane zostały na stronie: http:/ / naukawpolsce.pap.pl/aktualnosci/ news\%2C405803\%2Cna-rugii-odkryto-budowle-kultowa-z-czasow-slowian.html (dostęp: 18 VII 2015). 


\section{Bibliografia}

\section{Ź RÓDEA DRUKOWANE}

Annales Essenbecenses, ed. Societas Aperiendis Fontibus Rerum Germanicarum Medii Aevi, Hannover 1892, Monumenta Germaniae Historica, Scriptores, t. XXIX, s. 221-228.

Annales Lundenses, ed. Societas Aperiendis Fontibus Rerum Germanicarum Medii Aevi, Hannover 1892, Monumenta Germaniae Historica, Scriptores, t. XXIX, s. 185-209.

Ex Annalibus Islandicis, ed. Societas Aperiendis Fontibus Rerum Germanicarum Medii Aevi, Hannover 1892, Monumenta Germaniae Historica, Scriptores, t. XXIX, s. 252-266.

Ex Annalibus Waldemarianis et Vitescolensibus, ed. Societas Aperiendis Fontibus Rerum Germanicarum Medii Aevi, Hannover 1892, Monumenta Germaniae Historica, Scriptores, t. XXIX, s. 176-181.

Ex Chronica Danorum Sialandica, ed. Societas Aperiendis Fontibus Rerum Germanicarum Medii Aevi, Hannover 1892, Monumenta Germaniae Historica, Scriptores, t. XXIX, s. 210-216.

Ex Historia Danorum dicta Knytlingasaga, ed. Societas Aperiendis Fontibus Rerum Germanicarum Medii Aevi, Hannover 1892, Monumenta Germaniae Historica, Scriptores, t. XXIX, s. 271-322.

Ex Saxonis Gestis Danorum, ed. Societas Aperiendis Fontibus Rerum Germanicarum Medii Aevi, Hannover 1892, Monumenta Germaniae Historica, Scriptores, t. XXIX, s. 43-161.

Helmolda Kronika Słowian, przeł. J. Matuszewski, Warszawa 1974.

Helmoldi Presbyteri Bozoviensis Cronica Slavorum, ed. B. Schmeidler, Hannover 1937, Scriptores Rerum Germanicarum in usum scholarum.

Saxo Grammaticus, Gesta Danorum kronika Danii, przeł. J. Wołucki, Sandomierz 2014, Biblioteka Tradycji Europejskiej, nr 52.

\section{OpRacowania}

Banach S., Saxon, Slavs and conversion: Toward a New Understanding of Crusade, „Clio's Scroll” [Berkeley] 2016, vol. XVII, No. 1, s. 27-36.

Banaszkiewicz J., Czym była i jak została zniszczona choragiew Świętowita (Saxo Grammaticus, Gesta Danorum, XIV, 39, 14-28), [w:] W stronę rytuałów i Galla Anonima, Kraków 2018, s. 133-153.

Barkowski R.F., Połabie 983, Warszawa 2015, seria: Historyczne Bitwy.

Galas I., Od religio do superstitio wśród Słowian Połabskich według kronikarza Helmolda, [w:] Odkrywanie Europy Środkowej - od mitologii do rzeczywistości, red. M. Danielewski, R.R. Tomczak, Poznań 2016, Publikacje Instytutu Historii 143 , s. 25-32.

Gieysztor A., Mitologia Słowian, Warszawa 2006, seria: Communicare. 
Kajkowski K., Kuczkowski A., Religia Pomorzan we wczesnym średniowieczu, Pruszcz Gdański 2010, Etnografia dla każdego, nr 2.

Łowmiański H., Religia Słowian i jej upadek, Warszawa 1986.

Milewski T., Pierwotne nazwy wyspy Rugii i słowiańskich jej mieszkańców, „Slavia Occidentalis" 1930, t. IX, s. 292-306.

Modzelewski K., Barbarzyńska Europa, Warszawa 2004.

Myśliński K., Bogusław I książę Pomorza Zachodniego, Bydgoszcz-Gdańsk-Szczecin 1948.

Rosik S., Interpretacja chrześcijańska religii pogańskich Słowian w świetle kronik niemieckich XI-XII wieku (Thietmar, Adam z Bremy, Helmold), Wrocław 2000, Historia CXLIV.

Słownik starożytności słowiańskich, red. G. Labuda Z. Stieber, t. IV, WrocławWarszawa-Kraków 1970.

Słownik starożytności słowiańskich, red. G. Labuda Z. Stieber, t. VII, WrocławWarszawa-Kraków 1982.

Soszyński J., Święty Wit a Świętowit Rugijski. Z dziejów legendy, „Przegląd Humanistyczny" 1984, t. XXVIII, nr 9/10, s. 133-139.

Strzelczyk J., Słowianie Połabscy, Poznań 2013.

Vlasto A.P., The entry of the Slavs Into Christendom. An Introduction to the Medieval History of the Slavs, Cambridge 1970.

\section{Netografia}

http: / / naukawpolsce.pap.pl/aktualnosci/news\%2C405803\%2Cna-rugiiodkryto-budowle-kultowa-z-czasow-slowian.html (dostęp: 18 VII 2015).

www.dmgh.de/de/fs 1/object/display.html?sortIndex=010:070 (dostęp: 25 V 2018). www.ocf.berkeley.edu/.../Saxon-and-Slavs-and-Conversion (dostęp: 1 II 2018).

IwONa GaLas

Centre for Historical Studies

\section{The account of Slavic Rani in the medieval chronicles of Helmold and Saxo Grammaticus}

\footnotetext{
$\mathrm{T}$
} he Rani, a west Slavic tribe based on the island of Rugen, built an empire existing until $12^{\text {th }}$ century. In 1168 Rani were defeated by Danish king Valdemar I, resulting in the conversion of the tribe to Christianity.

The Chronica Slavorum by Helmoldus and Gesta Danorum by Saxo Grammaticus are quite commonly quoted sources in the debate concerning Slavic paganism and the attempts of its Christianization. What constitutes high-value Helmoldus' and Saxo's works is the fact that the chronicles are an essential and primary 
sources when it comes to the history of the Polabian tribes - their territories and their neighboring peoples. It is also a vital link in the account of the course of Christianization on the Polabian territory.

After the invasion of The Danish king Valdemar I the pagan temple, situated on the island, was destroyed and both the territorial and religious autonomy of the Rani ended.

At the tip of Arkona in recent centuries, the cliffs have collapsed into the sea and the chronicles still remain as witnesses of the Slavic history of Rugen.

Keywords: Slavs, Rugen, medieval chronicles, paganism, Christianization. 